\title{
The use and abuse of dogs on Scott's and Amundsen's South Pole expeditions \\ Carl Murray
}

Institute of Antarctic and Southern Ocean Studies, University of Tasmania, Private Bag 77, Hobart, Tasmania 7001, Australia

\section{Received January 2008}

ABSTRACT. In the century since Roald Amundsen and Robert F. Scott led the first and second expeditions to reach the South Pole, commentators have frequently passed judgement on the different means of transport that the two explorers employed. In hindsight, and since he 'won,' they have consistently praised Amundsen for using dogs exclusively and criticised Scott for not doing the same. Surprisingly, however, almost no attention has been given to the experience of Amundsen's dogs, whose extreme suffering seems to have vanished into a collective blind spot. Here, with the aim of restoring balance to one part of the vexed historiography of the two explorers, that record is set straight. Amundsen's troubled and contradictory attitude towards his animals is also explored and common misconceptions about Scott's views on the use of dogs for transport are confuted.

\section{Contents}

Introduction

Misconceptions about Scott's attitudes to dogs

'Pain, suffering, and death'

Two faces of Amundsen

A pyrrhic victory?

Acknowledgements

References

303

\section{Introduction}

When, after all the aeons, human feet finally trod the snow at the South Pole for the first time almost a hundred years ago, it was not one expedition but two that came: Roald Amundsen's on 14 December 1911 and, 34 days later, Robert Scott's. Mixed with the Norwegian boot marks were the prints of dogs, but with the boot marks of the British there were none. Dogs had indeed pulled some of Scott's sledges the first 425 miles $(684 \mathrm{~km})$ : all the way across the Ross Ice Shelf. But from there they were sent back and the men did their own hauling, 125 miles $(201 \mathrm{~km})$ up the Beardmore Glacier to the polar plateau at an altitude of 8000 feet $(2438 \mathrm{~m})$ and a further 350 miles $(563 \mathrm{~km})$ to the pole. As is well known, many hundreds of miles into their return journey and just short of a large food and fuel depot, Scott and his two surviving companions perished, while Amundsen's party returned alive and triumphant. At the time of the events, the expert view in England had been that dogs were of dubious value as a means of Antarctic transport. No less a figure than Ernest Shackleton, widely celebrated for having got much further south in 1909 than anyone before him, commented when he heard the Norwegians were in Antarctica:

I cannot see how Amundsen can hope to reach the South Pole unless he has a large number of ponies on board. He may have dogs, but they are not very reliable. I consider it now almost a sine qua non that any expedition trying for the South Pole should have horses.... (Shackleton Evening Standard 4 October 1910)

In view of this, it might seem prudent on Scott's part that he took ponies and experimental motor transport in addition to dogs. But almost all of the commentary in the ensuing century has, in hindsight, praised Amundsen ('the professional') for depending on dogs entirely and blamed Scott ('the amateur') for not doing the same. In 1928, Antarctic historian J. Gordon Hayes found his countryman's failure to do so 'positively irritating' (1928: 204), and about the British man hauling their own sledges he snorted: 'we shall surely hear no more of that absurd method of Polar travel' (1928: 179). Four decades later, even such a sympathetic biographer as Reginald Pound, while acknowledging that Scott's preference for man hauling over dog sledges was based on experience, regarded it as sentimental rather than logical (1966: 7477). And in 1996 Francis Spufford, dismissive of virtually everything he believed Scott stood for, wrote: 'If he were Amundsen ... he could take the continent at a dogpowered glide' (1996: 317). Almost the only author to have considered this question from the point of view of the dogs is Scott himself. This article does the same, and demonstrates that Amundsen achieved victory only at a tremendous cost to his animals and concomitantly, perhaps, to himself.

It is necessary to preface the discussion that follows with a brief comment about its context. In the last few decades the historiography of the Antarctic heroic age has been plagued by partisanship. Explorers have gone in and out of fashion and there has been a tendency to champion the current favourite while attacking 'the opposition.' Dubious reasoning and cheap shots have been common, and Scott has been a favourite target. (For a detailed analysis of the history of interpretation of Scott's story, see Murray 2006.) Although this practice may appeal to the love of taking sides and will sell 
books, it has done little for the quality of scholarship. The present article also portrays the two explorers in sharp contrast: there is no way of avoiding this, since the aim is to restore some balance to one part of the long record of adulation of Amundsen and denigration of Scott. But instead of relying on supposition or personal preference, the argument is based on Amundsen's own evidence from his published account of the Norwegian expedition. Before considering the experience of Amundsen's dogs, however, it is necessary to dispel three misconceptions of the anti-Scott canon: that the explorer did not appreciate what dogs could do; that, as an Englishman, he was prejudiced against using them for transport; and that he chose man hauling instead because it was nobler and more virile (for the last, see also Jones 2003). Here too Scott's own statements will be used as evidence.

\section{Misconceptions about Scott's attitudes to dogs}

The following quotation from Scott's book on his first, Discovery, expedition is regularly given to justify the three criticisms just listed: for example by Huntford (1993), Katz and Kirby (1991) and Rosove (2000). Rosove even quoted this passage, 'this hidebound view', to support his claims that Scott was 'too sentimental to make serious beasts of burden' of dogs and was 'disdainful of their role' before the push south on his first Antarctic expedition (Rosove 2000: 91-92), when in fact it was written as a result of the experience on that journey, as we will see.

In my mind no journey ever made with dogs can approach the height of that fine conception which is realised when a party of men go forth to face hardships, dangers, and difficulties with their own unaided efforts, and by days and weeks of hard physical labour succeed in solving some problem of the great unknown. Surely in this case the conquest is more nobly and splendidly won (Scott 1905: 343).

Certainly these lines appear to offer good evidence for the last of the claims referred to above. They are not, however, from the journal Scott kept in Antarctica: he wrote them back in England, and, while preparing his book, he was lunching daily at the house of his elderly patron, Sir Clements Markham, who was known to advocate this view (Lewis-Jones 2005: 197). Much later, in The lands of silence, Markham referred to this as 'one of the noblest passages in Scott's great work' (1921: 472). But he was careful to explain the context of the quotation and to include the sentences that precede it, both of which, as will be seen, are vital.

In any case, Markham's attitude to the use of dogs had, in part, also become Scott's own, in reaction to the latter's experience on the Discovery expedition. In the southern summer of 1902-1903 Scott, Wilson and Shackleton had made a 93 day, 960 mile $(1545 \mathrm{~km})$ journey south. This was by far the longest and southernmost sledging expedition in Antarctica to that date. Dogs pulled the sledges at first and Scott's diary was full of optimism: '... our hopes ran high for the future... Confident in ourselves, confident in our equipment, and confident in our dog team, we can but feel elated with the prospect that is before us' (1905: 18). From that point, however, their fortunes reversed. Partly as a result of tainted food, the dog teams 'seemed to lose all heart,' and soon the party had to carry half their load ahead and return for the rest, thus covering three miles in order to advance one. As they laboured on, the dogs had to be whipped to get them to move and some grew sick and died or were shot to feed the others. Later, the men released the surviving animals to follow the sledge, or even carried them on it. Finally there were no dogs left. Wilson described the experience as 'soul sickening' (1966: 220) and it also had a powerful effect on the sensitive Scott, whose sympathy for the suffering of all kinds of animals was well documented by his companions on both Antarctic expeditions.

But Scott's perspective was far more complex than the single quotation usually given suggests, especially since that quotation excludes essential context. It is taken from a disquisition on dogs as a means of polar transport that runs for more than seven pages (Scott 1905: 340-347), all written after Discovery's return, and it provides a good example of how misleading quotation can be. A summary of what precedes the fragment generally cited will be given, in order to show that Scott certainly appreciated the advantages of dog travel and that it was not prejudice, but compassion, that later prevented him from relying on them to the degree that Amundsen did. All of this was written long before Scott's famous last Terra Nova expedition, and at a time when there was no other Antarctic explorer he needed to compare himself with in this regard:

Broadly speaking, there are two ways in which dogs may be used-they may be taken with the idea of bringing them all back safe and sound, or they may be treated as pawns in the game, from which the best value is to be got regardless of their lives. (Scott 1905: 340)

If the first method was chosen, Scott calculated, a dog could pull a heavy load about $25 \%$ further than a man consuming an equivalent amount of food, and a light load $50 \%$ further:

To this may be added that the dog requires no sleeping-bag, tent or cooking-apparatus, nor, indeed, any of those articles which figured so largely as the permanent weights of a sledge party... So far, then, it would appear that a dog is a more efficient machine than a man; but, on the other hand...dogs cannot travel without man, and they have therefore, in addition to their own food, to carry the food and impedimenta of their drivers (1905: 341).

Scott noted that the best performances of dogs had been 'little short of marvellous,' but that these had been 'on short journeys, over beaten tracks, and with a light load' and that for some reason (he admitted: 'the subject is complicated') no dogs had ever returned alive from a long and completely isolated Arctic journey. He stated that if, and only if, the comparison was made with a dog sledge journey which aimed to preserve the dogs' 
lives, 'I am inclined to state my belief that in the polar regions properly organized parties of men will perform as extended journeys as teams of dogs.' On the other hand, if the lives of the dogs were to be sacrificed, then 'the dog-team is invested with a capacity for work which is beyond the emulation of men. To appreciate this is a matter of simple arithmetic', and Scott then performed the arithmetic (1905: 341). But efficiency notwithstanding, he expressed 'reluctance' to use dogs in this way:

One cannot calmly contemplate the murder of animals which possess such intelligence and individuality, which have frequently such endearing qualities, and which very possibly one has learnt to regard as friends and companions. On the other hand, it may be pointed out with good reason that to forego the great objects which may be achieved by the sacrifice of dog-life is carrying sentiment to undue length. It is a case, if ever there was one, where the end justifies the means. There is no reason why the life of a dog should be considered more than that of a sheep, and no one would pause to consider the cruelty of driving a diminishing flock of sheep to supply the wants and aid of the movements of travellers in more temperate climates (1905: 342).

Far from being the victim of 'British' dog-doting sentimentality and prejudice that his debunkers portray, Scott showed that he had thoughtfully considered both sides of this matter.

Public questioning of cruelty to animals had begun in England only about a century before Scott wrote those words, a development that coincided with the transition from a predominantly rural to a predominantly urban and industrial society. Change had been slow and hard won, and 'ridicule greeted every nineteenth-century proposal to widen the area of animals' protection' (Harrison 1973: 788). At first, horses and cattle attracted most of the reformers' attention; the use of dogs for pulling carts, for example, was not outlawed in London until 1839. Many of the reforms 'seemed to be directed at the pleasures and livelihood of the very poor' and the uneducated (Harrison 1973: 789), but that changed when the medical practice of vivisection came under scrutiny much later. In 1876 , for the first time, some legal restrictions were placed on the experimental use of animals, and the British Union for the Abolition of Vivisection was founded in 1898. The anti-vivisectionists were soon on the back foot, however, because of the obvious benefits for medical research from animal experimentation (Lansbury 1985: 153). As early as 1865 , the celebrated physiologist Claude Bernard, chief of a new medical priesthood, had proclaimed (notoriously from the anti-vivisectionists' point of view) that a physiologist was not like an ordinary person:

he is a man of science, absorbed by the scientific idea which he pursues: he no longer hears the cry of animals, he no longer sees the blood that flows, he sees only his idea... [so] we shall deem all discussion of vivisection futile or absurd... a man of science should attend only to the opinion of men of science who understand him....(1927: 103)
Coral Lansbury has described how tensions between an increasingly triumphalist medical profession and those opposed to vivisection erupted in violent confrontations over the symbolic statue of a dog in the London suburb of Battersea in 1907 (Lansbury 1985). But the prominence of the debate was short lived and the anti-vivisection movement soon failed badly. The use of animals for medical experimentation then flourished for many decades until the advent of the animal rights movement in the 1970s.

Writing two years before the Battersea riots, and about the use of animals in the Antarctic, Scott argued for a compromise: 'the avoidance of unnecessary pain' (1905: 342). At the same time he was forthright in acknowledging that his formative experience on the first southern journey had been:

probably... an exceptionally sad one in this respect, but it left in each one of our small party an unconquerable aversion to the employment of dogs in this ruthless fashion. We knew well that they had served their end, that they had carried us much farther than we could have got by our own exertions ....

He explained that he had tried to give a 'just view' of the use of dogs, and summarised:

To say that they do not greatly increase the radius of action is absurd; to pretend that they can be worked to this end without pain, suffering, and death is equally futile. The question is whether the latter can be justified by the gain, and I think that logically it may be; but the introduction of such sordid necessity must and does rob sledge-travelling of much of its glory (1905: 343).

The lines which are usually quoted, given at the start of this section, follow immediately. After such a balanced argument with its emphasis on pragmatism and logic, Scott's use of terms like 'glory,' 'nobly' and 'splendidly' for his peroration is probably unfortunate. But this does not excuse their quotation in isolation and the false impression thereby created. Dogs would remain a very important element in Scott's second quest for the pole but, as with the ponies, demands made of them would be subordinate to concern for their well being.

\section{'Pain, suffering, and death'}

Amundsen, by contrast, took an entirely utilitarian approach, with consequences for his animals that will now be examined. Scott had stated that it was futile to pretend that dogs could be employed in the way they later were on the Norwegian expedition without concomitant 'pain, suffering, and death', and indeed Amundsen's report of the experience of his dogs is replete with examples of all three. The facts will be presented as the explorer himself gave them in The South Pole. The expedition left Norway with 97 dogs (1976, I: 169). Additional females were apparently not needed and two puppies of that sex were the first animals to be killed, en route at Madeira (1976, I: 122). The dogs continued to breed and on arrival in Antarctica there were 116 (1976, I: 169). More puppies 
were dispatched later. Six females were shot, for example, at the Norwegian home base at the end of winter (1976, I: 346), and three whose sex is not stated were shot when they followed the expedition during an abortive early start for the pole (1976, I: 382). Adult dogs were killed or died of exhaustion throughout the expedition. On a depotlaying journey, one called Thor was killed with an axe. Another, Lurven, reduced to 'skin and bones,' 'fell down on the march and died on the spot. He was one of those dogs who had to work their hardest the whole time; he never thought of shirking for a moment; he pulled and pulled until he died.' Even at this early point, Amundsen stated: 'All sentimental feeling had vanished long ago ...' (1976, I: 242).

The South Pole journey took the heaviest toll of deaths. During the first stages dogs were killed because they were too old, too thin, pregnant or simply superfluous (1976, II: 22-29). 'The more we could get rid of,' Amundsen wrote at a certain point, 'and the sooner we could begin to do so, the better' (1976, II: 28). Not long afterwards, the mathematics of his plan demanded a mass slaughter, with a further six deaths held in abeyance:

We now had forty-two dogs. Our plan was to take all the forty-two up to the plateau; there twentyfour of them were to be slaughtered, and the journey continued with three sledges and eighteen dogs. Of these last eighteen, it would be necessary, in our opinion, to slaughter six in order to bring the other twelve back to this point (1976, II: 35).

At the point when the first of these killings took place, Amundsen made the candid comment: 'We had agreed to shrink from nothing in order to reach our goal' (1976, II: 62). Apart from the dogs that were killed, some that could not keep up were let go or ran away and were never seen again. More fell dead in their tracks. As devoted, hard working animals outlived their usefulness, they were summarily dispatched. Helge, 'an uncommonly useful and good-natured dog [who] without making any fuss ... had pulled from morning to night, and had been a shining example to the team,' was 'only a shadow of old Helge' on arrival at the pole: 'He was only a drag on the others and did absolutely no work. One blow on the skull, and Helge ceased to live' (1976, II: 123).

At times, there was an incongruous satisfaction in the perfunctoriness with which Amundsen described the killing of dogs on whose loyal service he had just remarked. Lasse, Amundsen's 'own favourite dog,' was the first to be killed on the return journey: 'He had worn himself out completely, and was no longer worth anything. He was divided into fifteen portions ...' (1976, II: 137). The incongruity was also evident in the relish with which the men ate the dogs: the thought of 'fresh dog cutlets,' Amundsen wrote, 'made our mouths water' (1976, II: 57). While he prefaced his description of the so-called 'Butcher's Shop,' where the mass slaughter took place, with some declarations of sadness, he was especially enthusiastic and graphic about the event itself: 'Great masses of beautiful fresh, red meat, with quantities of the most tempting fat, lay spread over the snow.' And as 'Rex, a beautiful little animal,' was being cut up: 'I could not take my eyes off [the] work; the delicate little cutlets had an absolutely hypnotizing effect as they were spread out one by one over the snow' (1976, II: 65).

When the expedition finally departed from Antarctica, there were 39 dogs left, about half of which had been with the expedition from the outset. Approximately 80 of the original $97 \mathrm{dogs}$, therefore, had either died or been killed, along with many others born during the expedition. On departure, when there was no particular need for it, Amundsen had planned to kill 21 of the remaining 39 dogs as superfluous to his breeding requirements, but spared them after his ship Fram returned with the news that Douglas Mawson had requested them for his Australian expedition (1976, II: 181).

From the death toll, we turn now to the dogs' suffering. Essentially this was of two kinds: either it was inflicted by the men to force the dogs to obey them or it was the result of the nature of the animals' work and the conditions in which they performed it. Early in his book Amundsen made it clear that he compelled absolute submission: 'the dog must understand that he has to obey in everything' (1976, I: 58). Later the author explained that he was aided by the fact that his 'Eskimo' dogs had a deeper fear of him than domestic dogs, the result of their stronger 'instinct of self-preservation' and their dependence on him for food (1976, I: 196-97). Nonetheless, submission was regularly enforced by whipping, of which there are many descriptions, particularly during the first sledging trips:

We had some work indeed, those first days, to get the dogs to obey us... More than once it cost us a wet shirt to convince them we were really the masters. It was strenuous work, but it succeeded in the end. Poor dogs! They got plenty of thrashing in those days (1976, I: 182).

The expression of pity and the wry references to the men's work and discomfort (wet shirts) divert attention from the harsh reality of the repeated flogging of the dogs. This early cowing of the animals and the traditional view of Amundsen as a complete master of dog driving notwithstanding, he too experienced runaway dog-teams. And later in the expedition his dogs still 'had to be flogged home' (1976, I: 377) and physically punished (1976, II: 16, 21).

The animals were also suffering from their work. At times they were shivering constantly and so cold that they had to be lifted up and put into harness (1976, I: 384). And despite the careful mathematics by which the dogs were fed to each other and to the men, they were also ravenously hungry. En route to the Pole, they would eat 'whips, ski-bindings, lashings, etc.' and Amundsen added: 'With some of them this voracity went so far that we had to chain them' (1976, II: 40). At the Pole, 'these ravenous animals ... devoured everything they came across, even to the ebonite points of our ski-sticks ...' (1976, II: 110111). They were required to perform gruelling work all the 
same. On an early depot laying trip Amundsen pushed on with dogs that were 'very thin, and apparently worn out; but in any case we had to reach $82^{\circ} \mathrm{S}$...' (1976, I: 234). Closer to that target, the dogs were 'terribly emaciated' (1976, I: 236), and when they finally arrived Amundsen acknowledged he had:

asked more of them than they were capable of doing ... The whip had long ago lost its terrors. When I tried to use it, they only crowded together, and got their heads as much out of the way as they could; the body did not matter so much (1976, I: 237).

One dog that died had been:

uttering his plaintive howls on the march, a thing one never hears a dog do while working. I did not understand what it meant-would not understand, perhaps. On he had to go- on till he dropped. When we cut him open we found that his whole chest was one large abscess (1976, I: 238).

Others were in a similar state. On the return from the pole, when Fritjof was cut open, it was discovered that his 'lungs were quite shrivelled up' (1976, II: 160). Although the internal condition of these dogs may not have been apparent to Amundsen at the time, he later wrote at the beginning of his book: 'the dogs were always in splendid condition' (1976, I: 56). He has been taken at his word. Turley, for example, an early biographer, told us merely that Amundsen 'loved his dogs' (Turley 1935: 80).

The point of enumerating all this suffering and death, therefore, is that very few commentators have either noticed it or found anything to object to in it. On the contrary, Scott has been widely criticised from the beginning for not employing the same means. The torment of the animals, it seems, has vanished into a collective blind spot.

Amundsen's and Scott's men seem to have been mostly silent about this matter. Helmer Hanssen, virtually the only member of the Norwegian polar team apart from the leader to have been published in English, wrote tactfully and politely:

... it was no fun for the dogs. They had to be driven hard and whipped if we were ever to get there [the Pole] in fact. . . We started with 52 dogs and came back with eleven, and many of these wore themselves out on the journey. What shall we say of Scott and his comrades, who were their own dogs? Anyone with any experience will take off his hat to Scott's achievement. I do not believe men ever have shown such endurance at any time, nor do I believe there ever will be men to equal it (Hanssen 1936: 105-113).

And on the British side, Apsley Cherry-Garrard wrote about Amundsen going 'so gaily to the Pole and back: with no abnormal strain on men or dogs ....' (1994: 563).

An extremely rare exception in all the subsequent commentary was 'Dogs' by New Zealand poet Bill Manhire. The poem detailed some of the animals' suffering and showed Amundsen trying to write a little poetry but without success: 'sometimes/ I feel quite alone.
It is hard almost to speak ... [let alone write poetry]/My best friends bark in my stomach...' (Manhire 2005).

\section{Two faces of Amundsen}

The explorer's harsh treatment of dogs probably did not begin with the Fram expedition. A member of the earlier Northwest Passage voyage wrote in his diary: 'He [Amundsen] either knows no better, or he enjoys tormenting animals' (Bomann-Larsen 2006: 40). But in any case, in the quest for the pole, by his own admission, Amundsen acted on the basis that the end justified any means. Whether one agrees with him or not, there is cognitive dissonance at least and perhaps hypocrisy in his attempts in The South Pole to appear as an animal lover despite the evidence of his actions, something which has previously been overlooked.

Amundsen had read Scott's The Voyage of the 'Discovery' and, early in The South Pole, linked his own statement about the need for absolute domination over dogs with some heavy irony regarding their use by the British: 'Can it be that the dog has not understood his master? Or is it the master who has not understood his dog?' (1976, I: 58); 'It must be rather hard to have to abandon one's motive power voluntarily when only a quarter of the distance has been covered. I for my part prefer to use it all the way' (1976, I: 59).

But the explorer also revealed his awareness that the treatment of animals was a topic of some sensitivity:

I still cannot help smiling when I think of the compassionate voices that were raised here and there-and even made their way into print-about the "cruelty to animals' on board the Fram. Presumably these cries came from tender-hearted individuals who themselves kept watchdogs tied up (1976, I: 60).

Whatever the conditions and treatment his dogs actually experienced while at sea, Amundsen's superior tone and irony here suggest a certain defensiveness, and throughout his book he was at pains to demonstrate his own sensitivity to the special qualities of dogs. 'There can hardly be an animal,' he wrote,

that is capable of expressing its feelings to the same extent as the dog. Joy, sorrow, gratitude, scruples of conscience, are all reflected as plainly as could be desired in his behaviour, and above all in his eyes. We human beings are apt to cherish the conviction that we have a monopoly of what is called a living soul; the eyes, it is said, are the mirror of this soul. That is all right enough; but now take a look at a dog's eyes, study them attentively. How often do we see something 'human' in their expression, the same variations that we meet with in human eyes. This, at all events, is something that strikingly resembles 'soul' (1976, I: 110).

The hint of didacticism in the imperatives, "now take a look... study them', may be Amundsen trying to persuade himself of his empathy, because it is difficult to square such a statement with the actual treatment of the dogs on the Fram expedition. Likewise, it was when 
the suffering inflicted first became obvious, when dogs dropped dead from exhaustion on a depot laying journey and 'the whip had long ago lost its terrors', that Amundsen first felt the need to justify his actions:

How hard and unfeeling one gets under such conditions; how one's whole nature may be changed! I am naturally fond of all animals, and try to avoid hurting them. There is none of the 'sportsman's' instinct in me; it would never occur to me to kill an animal-rats and flies excepted — unless it was to support life (1976, I: 238).

This seemingly reasonable statement bears further examination. The reference to the 'sportsman's instinct' may well be a deft swipe at the British hunting tradition, and there is deftness too in the wry exception made for 'rats and flies,' with agreement guaranteed from most readers. It is at least questionable whether such an animal lover as Amundsen here portrayed himself could treat animals the way he did. Scott could not. And there are two claims here which may be challenged on the author's own evidence. The first is the assertion that he took no pleasure in the hunting of animals. He described, for example, at considerable length 'an exciting seal-hunt' which occurred shortly after the Norwegians set up their base, and which he obviously found side-splittingly funny. At first he 'chuckle[d] and laugh[ed]' as he watched two men stalking the seals:

Then there is a report. Two of the sleeping seals give a little spasm, and do not move again. It is otherwise with the third. With snakelike movements it wriggles away through the loose snow with surprising speed. It is no longer target practice, but hunting real game, and the result is in keeping with it. Bang! bang! and bang again. One of the hunters uses up all his cartridges and has to go back, but the other sets off in pursuit of the game. Oh, how I laughed! Decorum was no longer possible; I simply shook with laughter (1976, I: 177-178).

Despite the fact that the seals were being hunted for food, Amundsen's hilarious enjoyment of their being used for 'target practice' and then shot at indiscriminately cannot easily be reconciled with the statements such as 'There is none of the "sportsman's" instinct in me' and 'I am naturally fond of all animals, and try to avoid hurting them.' Certainly the laughter in this episode was partly at the struggles of the hunters, but Amundsen showed no concern at all for the seal. On another occasion he described thrashing dogs in order 'to be revenged' for their disobedience, while emphasising the trouble this gave the driver (1976, I: 190). Furthermore, the claim that he would only kill an animal 'to support life' is belied by the previously mentioned fact that, before he was told of Mawson's request, he was intending to kill 21 of his remaining dogs before leaving the continent. And when one of the dogs gave birth to eight pups as the ship sailed north from Hobart later in 1912, 'four of these were killed, while the rest, two of each sex, were allowed to live' (1976, II: 353).
How do we explain these contradictions? In the first place, probably, by acknowledging that human beings are inconsistent, and rarely more so, Arnold Arluke and Clinton Sanders have pointed out (1996), than in their attitudes to animals. Certain theorists have emphasised the happiness they believe animals derive from successful cooperation with people. But while Amundsen did write about especially helpful and hardworking dogs, he did not claim, as Vicki Hearne did (1995), that their work fulfilled some innate purpose or desire of the animals themselves. Only on short journeys near home did Amundsen believe his dogs 'loved their harness' (1976, I: 187-188). More plausibly, critics like Barbara Noske have argued that there has been long-standing and systematic exploitation of animals by humans, and that this has become more extreme as animals have been 'incorporated into production technology' (Noske 1997: 14). Noske (1997: 53) and Ruth Wallsgrove (1980: 233) both pointed out that this exploitation requires a partitioning of human beings from the rest of the natural world and an objectification and depersonalisation of animals, and that this has been greatly strengthened by certain attitudes of modern science. Wallsgrove further believed that such attitudes with their concomitant detachment and denial of emotion (the words of the physiologist Bernard quoted above provide a striking example) form an unholy alliance with ideologies of masculinity. 'Science and masculinity,' she asserted, 'are one-half of an exaggerated polarity, a dangerous imbalance' (Wallsgrove 1980: 235). So it may be that Amundsen, in writing so candidly and at times with such apparent self satisfaction about the way he worked his dogs to death and converted them into consumables, was aligning himself with what he saw as an efficient modern technological outlook. There was, moreover, a decidedly 'masculine' flavour to his book. He was consistently dismissive of what were obviously, at the time, serious dangers and hardships. And on several occasions he linked the conquest of the pole to the winning or ravishing of a woman: 'The deity of success is a woman, and she insists on being won, not courted. You've got to seize her and bear her off, instead of standing under her window with a mandolin' (1976, I: 42, see also I: 179; I: 194). By contrast, and interestingly, Scott's 'feminine' qualities have sometimes been remarked on, first perhaps by one of the Terra Nova expedition's most famous members, Apsley Cherry-Garrard (1994: 466).

\section{A pyrrhic victory?}

Whatever the reasons for Amundsen's contradictory attitudes to his dogs, it seems that, after the event, he felt some pangs of conscience about this matter and in his book attempted to justify himself in retrospect. Some of the statements he made in doing so were inaccurate. In places, however, he was more honest in his remorse and admitted that he was brutalised by his monomania with being first at the pole. Of the time he drove the dogs to death on the depot laying journey to $82^{\circ} \mathrm{S}$, he wrote: 
'the daily hard work and the object I would not give up had made me brutal, for brutal I was when I forced those five skeletons to haul that excessive load' (1976, I: 238). Arluke and Sanders have drawn attention to the potential costs both for the individual and for society of 'allowing, or even condoning' such contradictions, on the grounds that this 'dulls our moral sensitivities.' Accordingly, they suggested that it was 'appropriate and healthy to challenge' them, as this article has attempted to do (1996: 190).

When considered solely as an example of the singlemindedly determined prosecution of a great and arduous plan, Amundsen's South Pole expedition is unsurpassed. But his conduct had serious consequences for others. Here, some of the consequences for his animals have been described. It is therefore not surprising that part of the personal cost to Amundsen of his triumph was a certain brutalising of character, which he acknowledged. The Norwegian psychoanalyst Per Anthi believed, moreover, that the explorer experienced acute guilt at his South Pole victory for a variety of reasons and, through lack of insight into his inner conflicts, afterwards lapsed into paranoia (Anthi 1999). The Norwegian ambassador in London, Anthi added, later came to regard him as 'mentally deranged' and Fridtjof Nansen confirmed that 'there were several unmistakable signs of insanity' (1999: 1003). (Nansen himself had previously felt 'bitter self-reproach' for 'undeniable cruelty' to his own dogs in the Arctic two decades earlier (Quoted in Fiennes 2003: 66), but was apparently better able to deal with his guilt.)

Such aspects of Amundsen's personality and subsequent life, hitherto little known to readers of English, are extensively documented in a recently translated Norwegian biography (Bomann-Larsen 2006).

Apart from the personal cost, there may also be broader implications, as Arluke and Sanders suggested, of overlooking or condoning certain aspects of Amundsen's conduct. By his own admission, the explorer was ruthless in the pursuit of his goal and used it to justify questionable behaviour of various kinds. The most-debated instance is the concealment of his plan to attempt the pole and Bomann-Larsen's biography contains many additional examples. Subsequently, Amundsen's attainment of that goal also justified in the eyes of many the means he had employed. Scott had foreseen that this would happen, writing to his New Zealand agent Joseph Kinsey when he learned of Amundsen's presence in Antarctica: 'If he gets to the Pole he is bound to do it rapidly with dogs and one foresees that success will justify him and that our venture will be "out of it"' (1911). 'In victory, there are no questions asked,' Roland Huntford, a hero worshipping biographer of Amundsen, stated in an early article he co-authored: 'After Roald Amundsen won the race for the South Pole... very few cared how he did it, least of all himself' (Drewry and Huntford 1979: 329). The last four words of this quotation are, as we have seen, not quite accurate. And this points to a broad potential distinction between the two expeditions, just one aspect of which has been examined here: a distinction between means and ends which is as vital today as it was a century ago in Antarctica. Is the achievement of personal success paramount, and so the greater the success the more ruthless the behaviour it can justify? Or must the pursuit of success be subordinate to correct conduct and a concern for others, nonhuman as well as human? These questions might be borne in mind when assessing Amundsen's Antarctic achievements and comparing them with those of Scott, as might the very different fates of the two explorers' dogs.

\section{Acknowledgements}

I am grateful to the three anonymous referees of this journal whose thoughtful comments forced me to scrutinise and, I hope, improve what I had written. I would also like to record my gratitude to Elizabeth Leane of the University of Tasmania's School of English, Journalism and European Languages for her ever-generous and perceptive support.

\section{References}

Amundsen, R. 1976. The South Pole: an account of the Norwegian Antarctic Expedition in the 'Fram,' 19101912 (translator A.G. Chater). St. Lucia: University of Queensland Press (facsimile of original work published in 1912).

Anthi, P.R. 1999. A study in rivalry, masochism and paranoia. International Journal of Psychoanalysis 80: 995-1010.

Arluke, A., and C.R. Sanders. 1996. Regarding animals. Philadelphia: Temple University Press.

Bernard, C. 1927. An introduction to the study of experimental medicine (translator H.C. Greene). New York: Macmillan (original work published in French in 1865).

Bomann-Larsen, T. 2006. Roald Amundsen. (translator I. Christophersen). Phoenix Mill: Sutton.

Cherry-Garrard, A. 1994. The worst journey in the world. London: Picador (original work published in 1922).

Drewry, D.J., and R. Huntford. 1979. Amundsen's route to the South Pole. Polar Record 19(121): 329-336.

Fiennes, R. 2003. Captain Scott. London: Hodder.

Harrison, B. 1973. Animals and the state in nineteenthcentury England. The English Historical Review 88: 786-820.

Hanssen, H. 1936. Voyages of a modern viking. London: Routledge.

Hayes, J.G. 1928. Antarctica: a treatise on the southern continent. London: Richards.

Hearne, V. 1995. Animal happiness. New York: Harper.

Huntford, R. 1993. Scott and Amundsen. London: Weidenfeld (original work published in 1979).

Jones, M. 2003. The last great quest: Captain Scott's Antarctic sacrifice. Oxford: Oxford University Press.

Katz, C., and A. Kirby. 1991. In the nature of things: the environment and everyday life. Transactions of the Institute of British Geographers 16: 259-271.

Lansbury, C. 1985. The old brown dog: women, workers, and vivisection in Edwardian England. Madison: University of Wisconsin Press. 
Lewis-Jones, H.W.G. 2005. 'Heroism displayed': revisiting the Franklin Gallery at the Royal Naval Exhibition, 1891. Polar Record 41(218): 185-203.

Manhire, B. 2005. Dogs. London Review of Books 3 March 2005: 6.

Markham, C.R. 1921. The lands of silence: a history of Arctic and Antarctic exploration. Cambridge: Cambridge University Press.

Murray, C. 2006. 'Scott of the Antarctic': the conservation of a story. Unpublished $\mathrm{PhD}$ thesis. University of Tasmania. URL: http://eprints.utas.edu.au/2627/.

Noske, B. 1997. Beyond boundaries: humans and animals. Montreal: Black Rose.

Pound, R. 1966. Scott of the Antarctic. London: Cassell.

Rosove, M.H. 2000. Let heroes speak: Antarctic explorers, 1772-1922. Annapolis: Naval Institute.

Scott, R.F. 1905. The voyage of the 'Discovery' (Vol 1). London: Macmillan.
Scott, R.F. 1911. Letter to Joseph Kinsey. 28 October 1911. Wellington, New Zealand: Alexander Turnbull Library, Tapuhi collection Ms. Papers-0022-06 (Official Correspondence, Captain R.F. Scott to J.J. Kinsey 1901-1911).

Spufford, F. 1996. I may be some time: ice and the English imagination. London: Faber.

Turley, C. 1935. Roald Amundsen, explorer. London: Methuen.

Wallsgrove, R. 1980. The masculine face of science. In: Birke, L., W. Faulkner, S. Best, D. Janson-Smith, and K. Overfield (editors). Alice through the microscope: the power of science over women's lives. London: Virago: 228-240.

Wilson, E. 1966. Diary of the 'Discovery' expedition to the Antarctic regions 19011904. (editor A. Savours). London: Blandford. 